\title{
The Roles of Victims in the ICC: Victims' Protection or the Accused's Fair Trial Right Violation?
}

\author{
Mahfud \\ Faculty of Law, University of Syiah Kuala, Indonesia. \\ E-mail: mahfud_jufri@unsyiah.ac.id
}

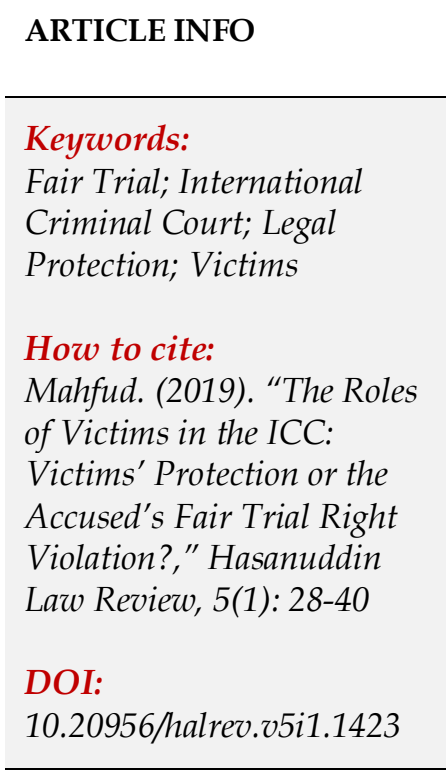

\begin{abstract}
The International Criminal Court (ICC) has provided the right to present victims views in the ICC's proceeding. The objectives of this article are to identify to which extent the roles of victims in the ICC and to analyze whether victims' participation would be a violation to the rights of a fair trial of the accused in the ICC or not. This is pure legal research meaning that the materials required in this article are available in libraries, archives and other databases. The article concludes that the victims, in the ICC, are allowed to participate and to seek reparation in accordance with Article 68 (3) of the Rome Statute. In addition, the participation would violate the due process rights of the defendants despite the fact at a particular case; the Appeal Chamber of the ICC decided that there is no such violation as aiming at ending individual impunity.
\end{abstract}

\section{Introduction}

There is a large amount literature available concerning the rights of victim in the International Criminal Tribunal for Former Yugoslavia (ICTY) and the International Criminal Tribunal for Rwanda (ICTR). The right to have information of the family of disappeared victim in the ICTY has been studied by Giovanna M. Frisso. ${ }^{1}$ The rights of the victims before the Extraordinary Chamber of Cambodian Court has been discussed by David Boyle. In addition, Colin T. McLaughlin has analyzed the ICC's extensive victim measure. Moreover, the roles of victims in seeking reparation in the ICC through the ICC's Trust Fund has been researched by Liesbeth Zegveld. However, the previous researches did not look deeply into whether the victims' roles before the ICC would be violating the rights of a fair trial of the accused. Therefore, this article will identify both the roles of victims before the ICC, as well as to identify whether such extensive roles would breach the right of a fair trial of the accused in the trial of the ICC.

1 Giovanna M. Frisso (2011). “The Winding Down of the ICTY: The Impact of the Completion Strategy and the Residual Mechanism on Victims". Goettingen Journal of International Law, 3, 1093, p. 1096. 
The protections of victims have developed from the insert of ICTY, and then the Rome Statute established the International Criminal Court (ICC) in 1998. The ICTY regulated the standard on victims' protection by the reliance on different national court systems and also on international benchmark, hence other international criminal tribunals, namely the ICTR and the Special Court for Sierra Leone (SCSL), have adopted the approach. ${ }^{2}$

In relation to the victims of international criminal crimes, unfortunately, they have a peripheral role in the in the creation and work of the tribunals and also in the design of their completion strategy and the establishment of the residual mechanism that they have to deal with. ${ }^{3}$ Despite the fact that the ICC has adopted the benchmark of the tribunals, it is still unknown that how well the ICC is going to protect victims, if the Rules of Procedure and Evidence (later called as RPE) are going to provide proper protection for the victims. ${ }^{4}$ However, it has been an unprecedented approach of the ICC as besides providing prosecution and punishment of individuals committing atrocity crimes, the ICC also regulates a legitimate participation for the individual as a victim. ${ }^{5}$

It is not only an unprecedented approach but also revolutionary in terms of the acknowledgement towards victims' participation and reparations in the international criminal justice. The ICC has allowed victims to present their views on the assessment to an investigation authorization, the case admissibility, and issues affecting their personal interest. ${ }^{6}$ Their involvement would not only be ensuring victims' interests but also helping to restore victims' dignity, avail the process of reconciliation, and take small facts and proofs that could be used at trial. ${ }^{7}$

The reasons for allowing them to participate are avoiding secondary victimization, contributing to their rehabilitations, seeking their reparations and leading to more successful prosecutions. ${ }^{8}$ Despite the fact that the victims' participation in criminal proceedings benefits them, it has been argued that it might be unduly to prejudice the accused and to cause substantial administrative costs. ${ }^{9}$ In addition, Christine Byron argues that it is far too early to assume that the ICC as the permanent body having jurisdiction over war crimes in international and internal conflicts will have enough support to provide an effective mechanism for the enforcement of international humanitarian law. ${ }^{10}$ Thus, it is the fact that every traditional method of enforcing international humanitarian law has significant weaknesses. ${ }^{11}$ The result from such weaknesses is that the victims of many conflicts have been left with no recourse other than regional or international human rights institutions. ${ }^{12}$

\footnotetext{
2 Colin T. McLaughlin (2007). "Victim and Witness Measures of the International Criminal Court: A Comparative Analysis". The Law and Practice of International Courts and Tribunals, 6, 189, p.189

10 C. Byron (2007). “A Blurring of the Boundaries: The Application of International Humanitarian Law by Human Rights Bodies". Virginia Journal of International Law, 47, 839, p.846-847.

$11 \quad$ Ibid. p. 847.

12 Ibid.
} 
The ICC is not only as a permanent criminal court with jurisdiction over individuals for the most serious atrocities of international concern but also as the Court having a completely new system for victims participation in criminal proceedings during the trial stage and pre-trial stage. ${ }^{13}$ One of the Court tasks is to establish the truth and in this matter, victims' participation may help to accomplish the goal. ${ }^{14}$ The participation of victims at the ICC is provided in the RPE from article 85 to 99 of the RPE the ICC. 15

Unlike the ICC, the Nuremberg Military Tribunal does not regulate its participation and even the ad hoc tribunals, ICTY and ICTR, are only limited provisions ruled the reparation and no provisions letting the victim participate other than witnesses. The United Nations' ad hoc Tribunals system excludes the participation regarding the mandate of tribunals, their nature and the structure of their procedural system (accusatorial common law procedural systems do not usually allow the participation). ${ }^{16}$ Nevertheless, the reparation for them resulted from serious violation of international criminal law has always been treated as a subject of secondary importance in international law. ${ }^{17}$ The concern about them has not received as great attention as perpetrators until recently their rights and interests have largely been overlooked.18

Therefore, this article explores the following research questions; to which extent the roles of victims in the International Criminal Court and whether victims' participation would be a violation to the rights of a fair trial of the accused in the International Criminal Court?

\section{The Roles of the Victims in the International Criminal Court (ICC)}

The RPE of the ICC have worded that victims are permitted to make general representations; get involved in reparation request, get entitled to jurisdiction, investigations, indictments and their changes, temporary release hearings, approval of hearings, admissibility hearing and related evidence, hearings on sentencing, and the case record access at the Registry. However, victims are not allowed to have an absolute participation right; victims' participation exist only if there is a personal interest in the special proceeding. ${ }^{19}$

In the prosecution of mass crime, there are other legal issues that are not clearly elaborated which require international legal precedents. For instance, domestic courts, international human rights courts, pre-existing international criminal tribunals, NGOs, and scholars have all viewed differently the victim participation matter in an international criminal proceeding. ${ }^{20}$ Application for a victim status is regulated in the

13 Miriam Cohen (2008). "Victims' Participation Rights Within the International Criminal Court: A Critical Review". Denver Journal of International Law and Policy, 37, 351, p.351.

$14 \quad$ Ibid. p.351.

15 Christodoulos Kaoutzanis (2010). “Two Birds with One Stone: How the Use of the Class Action Device for Victim Participation in the International Criminal Court Can Improve Both the Fight against Impunity and Victim Participation". U.C. Davis Journal of International Law \& Policy, 17, 111, p.118.

16 Salvatore Zapala (2010). "The Rights of Victims v. the Rights of the Accused". Journal of International Criminal Justice, 8, 137, p. 138.

17 Liesbeth Zegveld (2010). "Victims' Reparations Claims and International Criminal Courts: Incompatible Values?". Journal of International Criminal Justice, 8, 79, p.79.

18 Ibid., p.80.

19 Christodoulos Kaoutzanis, Op.cit., p.125.

20 Jocelyn Courtney, Christodoulos Kaoutzanis (2015). “Proactive Gatekeepers: The Jurisprudence of the ICC's Pre-Trial Chambers". Chicago Journal of International Law, 15, 518, p.543. 
Rule of 89 of the RPE of the Rome Statute. ${ }^{21}$ After a victim status granted to the applicant, the road to victims to succeed their participations could be separated into three phases, namely: the certification of victims by the PTC, legal appointment of representation at the PTC, and the proceedings' participation. ${ }^{22}$ Thus, their roles in participating at the proceeding and seeking reparation in the ICC are going to be discussed in this paper.

The Rome Statute has introduced an unprecedented and inventory rule that permits victims to participate in a legal capacity from the investigation to the trial; hence they are not only as witnesses or the reparation recipients in most stages of the proceeding. ${ }^{23}$ It is said unprecedented as either the ICTY or the ICTR provide for such victims' participation scheme. ${ }^{24}$ Christine Van den Wyngaert, a Judge at the International Criminal Court since 2009 and a former Judge of the International Criminal Tribunal for the Former Yugoslavia between 2003 and 2009, states that despite the fact that the Rome Statue has been entering into force since 2002, the ICC is still a new Court dealing with multiple and immense challenges, one of the challenges is the role of victims before the Court and it would be one of the most important challenges in the upcoming years. ${ }^{25}$ The ICC is said to have changed a retributive judicial system to a more restorative justice system because the participation was not allowed at the previous ad hoc criminal tribunals, Nuremberg, ICTY, and ICTR tribunals. ${ }^{26}$ Ironically, such previous tribunals caused secondary victimization towards them due to a judicial process preventing them from participating fully. ${ }^{27}$

Unlike ICTY and ICTR statutes, it is considered that the ICC statute is called as victimfriendliness. ${ }^{28}$ The ICC has created Victims and Witnesses Unit providing protective measures for victims and witnesses. ${ }^{29}$ In addition, the Statute obliges the International Criminal Court to take proper measures to protect the safety, physical and psychological well-being, dignity and privacy of victim and witnesses. ${ }^{30}$ The main rule regarding the participation is Article 68, paragraph (3) stating that, "where the personal interests of the victims are affected, the Court shall permit their views and concerns to be presented and considered. ${ }^{31}$ This Article does not shift victims to real parties in the proceedings; they are only participants that are limited to raising views and concerns. 32

21 Rule 89 (1) of the Rules of Procedure and Evidence of the ICC, provides that: “In order to present their views and concerns, victims shall make written application to the Registrar, who shall transmit the application to the relevant Chamber [...] Subject to the provisions of the Statute, in particular article 68, paragraph $1[\ldots]^{\prime \prime}$

22 Christodoulos Kaoutzanis, Op.cit., p.118.

23 Kristina Hon (2013). "Bringing Cultural Genocide In By The Backdoor: Victim Participation at The ICC". Seton Hall Law Review, 43, 359, p. 381.

$24 \quad$ Ibid., p.381-382.

25 Christine Van den Wyngaert (2011). Victims Before International Criminal Courts: Some Views and Concerns of an ICC Trial Judge. Case Western Reserve Journal of International Law, 44, 475, p.476.

26 Ibid., p.476.

27 Ibid., p.477.

28 Ibid., p.479.

29 Rome Statute of the International Criminal Court Art. 43 (6), July 1, 2002, 2187 U.N.T.S.90.

30 The Rome Statute, Art. 68 (1).

31 Rome Statute of the International Criminal Court Art. 68 (3). Where the personal interests of the victims are affected, the Court shall permit their views and concerns to be presented and considered at stages of the proceedings determined to be appropriate by the Court and in a manner which is not prejudicial to or inconsistent with the rights of the accused and a fair and impartial trial. Such views and concerns may be presented by the legal representatives of the victims where the Court considers it appropriate, in accordance with the Rules of Procedure and Evidence.

32 Christine Van den Wyngaert, Op.cit. p.483. 
Nevertheless, their roles are exceeding the role of victims at the ad hoc tribunals, ICTY and ICTR even judges at the ICC have granted a quite broad interpretation of victims' rights. ${ }^{33}$ Under the ICC regime, victims are not only allowed to participate in cases but also in the level of the situation, the stage that is before the arrangement of charges arranged against a particular person. ${ }^{34}$ The Prosecutor should take into account the interest of victims in terms of initiating an investigation by informing the Pre-Trial Chamber. ${ }^{35}$ In addition, the Prosecutor also has to inform the Pre-Trial Chamber If, upon investigation, the Prosecutor concludes that there is not a sufficient basis for a prosecution because of the interests of victims. ${ }^{36}$ The Trial Chamber also provides very broad interpretation of the right, for instance in Lubanga, the Chamber at the beginning granted rights to participate in the proceeding not only for victims of the crimes charged but also to uncharged crimes victims. ${ }^{37}$ The impact of the broad participatory rights for victims is that the Chambers in holding the decisions must also consider the victims' submissions, apart from parties' submissions. ${ }^{38}$

Pursuant to the Rule 85 (a) of the RPE of the Rome Statute states that victims are "natural persons" or particular organizations and institutions that have "suffered harm as a result of the commission of any crime within the jurisdiction of the Court."139 The meaning of victim is widened in the United Nations Declaration of Basic Principles of Justice for Victims of Crimes and Abuse of Power as:
"Persons who, individually or collectively, have suffered harm, including physical or mental injury, emotional suffering, economic loss or substantial impairment of their fundamental rights, through acts or omissions that are in violation of criminal laws operative within Member States, including those laws proscribing criminal abuse of power... The term "victim" also includes, where appropriate, the immediate family or dependents of the direct victim and persons who have suffered harm in intervening to assist victims in distress or to prevent victimization." 40

One of the main purposes of the ICC is to protect and vindicate the victims of the most cruelest crimes, for instance the Trial Chamber must be held with full respect for the accused rights and due regard for the protection of victims and witnesses. ${ }^{41}$ Moreover, if the Trial Chamber considers that a more complete presentation of the facts of the case is needed because of the interest of justice, especially in the interest of the victims, the

33 Ibid. p.483.

$34 \quad$ Ibid. p.484

35 Rome Statute of the International Criminal Court Art. 53 (1) (c) Taking into account the gravity of the crime and the interests of victims, there are nonetheless substantial reasons to believe that an investigation would not serve the interests of justice. If the Prosecutor determines that there is no reasonable basis to proceed and his or her determination is based solely on subparagraph (c) above, he or she shall inform the Pre-Trial Chamber.

36 Rome Statute of the International Criminal Court Art. 53 (2) : If, upon investigation, the Prosecutor concludes that there is not a sufficient basis for a prosecution because (c) A prosecution is not in the interests of justice... the interests of victims and the age or infirmity of the alleged perpetrator, and his or her role in the alleged crime; the Prosecutor shall inform the Pre-Trial Chamber and the State making a referral under article 14 or the Security Council in a case under article 13, paragraph (b), of his or her conclusion and the reasons for the conclusion.

37 Christine Van den Wyngaert, Op.cit., p.485

$38 \quad$ Ibid. p.485

39 International Criminal Court, Rules of Procedure and Evidence, online: ICC <http://www.icccpi.int/en_menus/icc/legal\%20texts\%20and\%20tools/official\%20journal/Documents/RulesProc edureEvidenceEng.pdf. r.85(a).

40 Michael Bachrach (2000). "The Protection and Rights of Victims under International Criminal Law". Journal of International Law, 34 (7)., p.9.

$41 \quad$ Ibid. p.17. 
Chamber may demand the Prosecutor present additional proof and continue the trial even after the admissibility of guilt by the accused. ${ }^{42}$ This procedure may offer satisfaction and guarantee of non-repetition as required by the van Boven Principles. ${ }^{43}$ Nevertheless, the participation in proceeding and to which extent they can participate not able to be answered in general, it must be considered generally. ${ }^{44}$

Based on civil and common law justice system that criminal justice includes an violation against the state rather than an individual and victims are have rarely been granted a role, its fact also influences international crimes as crimes against international community rather than victims. ${ }^{45}$ However, the International Criminal Court intends to correct this perception. ${ }^{46}$ It can be seen from the United Nation Secretary General Kofi Anan statements at the opening of the final United Nations Diplomatic Conference of Plenipotentiaries on the Establishment of the Court that:

"[T]he overriding interest must be that of the victims, and of the international community as a whole. I trust you will not flinch from creating a court strong and independent enough to carry out its task. It must be an instrument of justice, not expediency. It must be able to protect the weak against the strong." 47

The Rome Statute regulates the most developed rules in relation to the protection of victims and their participation in the justice process although the idea was challenged during the negotiation of the statute. 48 The participation is one of the more controversial issues of the Rome Statute. ${ }^{49}$ The requirement to participate as a victim before the ICC is by making an application to the Registrar who then pass it to the Chamber and later it assesses whether a victim fulfills the Rule 85 of the RPE and whether a victim interest are influenced by the proceeding. ${ }^{50}$ Its interest has to be made in different form every time she or he applies for the participation at different procedural level through written submission on which the parties have a right to respond it. 51

Pursuant to Rule 91 (3) of RPE, it states that if a victim would like to question a certain witness, the legal representative has to submit a written request mentioning which questions they would like to ask and how further their interests. In practice, meaning that for every applicant, the Chamber has to decide based on prima facie assessment of the victim status of the person or organization in question. ${ }^{52}$ The ICC has been receiving 9,910 applications for participation but it is roughly only a third was approved to participate in the trial. ${ }^{3}$ 'Victims' participation for the first time can be seen from Thomas Lubanga Dyilo case. ${ }^{54}$ There were 127 victims allowed to participate in the case. ${ }^{55}$ In

$42 \quad$ Ibid. p.17.

43 Ibid.

44 Charles P Trumbull IV, Op.cit., p.791.

45 Kelisiana Thynne (2009). "The International Criminal Court: A Failure of International Justice For Victims?". Alberta Law Review, 46, 957, p.962.

$46 \quad$ Ibid. p.962.

$47 \quad$ Ibid. p.962.

48 Ibid. p.963.

Ibid. p.476.

Ibid. p.482.

Ibid. p.482.

Christine Van den Wyngaert, Op.cit., p.481.

3 Ibid. p.482.

54 Prosecutor v. Thomas Lubanga Dyilo, ICC-0 1/04-01/06, Judgment on the appeals ofThe Prosecutor and The Defence against Trial Chamber l's Decision on Victims' Participation of 18 January 2008 (11 July 2008) at para. 96 (International Criminal Court, Appeals Chamber): online <http://www.icccpi.int/iccdocs/doc/doc258420.PDF.

55 Christine Van den Wyngaert, Op.cit., p.482. 
addition, 366 victims were approved to participate in the Katanga case and 1889 were participating in Bemba case. 56 The important rule regarding its participation can be seen in Article 68, paragraph 3, stating that: "where the personal interests of the victims are affected, the Court shall permit their views and concerns to be presented and considered." 57

They are allowed to participate at all stages of proceedings; Pre-Trial, Trial and Appeals Chambers. ${ }^{58}$ At pre-trial, the victims' role consists of the right to attend public sessions of the confirmation hearing and to present views and concerns. ${ }^{59}$ At the trial stage, they are approved to question witnesses presented both by the Prosecution and the Defense, and they have also been granted the opportunity to suggest evidence to the Trial Chamber but they are banned to call such evidence themselves. ${ }^{60}$ Furthermore, they can also apply to be listened as witnesses, separately of the Prosecutor or the Defense. ${ }^{61}$ The right of victim to participation under the ICC has indeed been praised as one of the significant achievements of modern era international criminal justice. ${ }^{62}$

The presence of victims in the proceedings is similar to civil trials; they are also entitled to seek financial reparations. As a consequence, the defendants have confirmed to be poor. In order to avoid victims from being not compensated, the Statute of Rome has anticipated it by providing a Victims' Fund, which is mainly derived from Member States donation. However, if the accused has possessions, such properties would be confiscated as an additional budget of the existing fund. The ICC assigns the monetary compensation to help victim suffering of injuries at a communal scope that might assist the victims of perpetrators who are held not liable for committing such atrocities by the ICC. 63

In addition, the aforementioned victims might also be granted reparations at the end of the trial by the court due to their suffering as crime victims and they have a role in helping the court to determine the amount of it by making submissions to the Chamber. ${ }^{64}$ It seems that the Rome Statute is not clearly regulating about the reparations hence it is left to the ICC to decide its meaning, even it is claimed as a constructive ambiguity in the Statute putting a high responsibility on the judges' shoulders. ${ }^{65}$ It can be seen in Article 75 of the Statute. 66 Moreover, they are also allowed to appeal reparation decisions despite the fact that in the end sentencing process their participation is limited to question of reparations. ${ }^{67}$ The 1985 Declaration of Basic Principles of Justice influenced the wording of the participation and reparation in the ICC Statute for Victims of Crime and Abuse of Power that was adopted by the United Nation General Assembly.68 In Lubanga case, the Appeals Chamber decided that " although the right to lead evidence

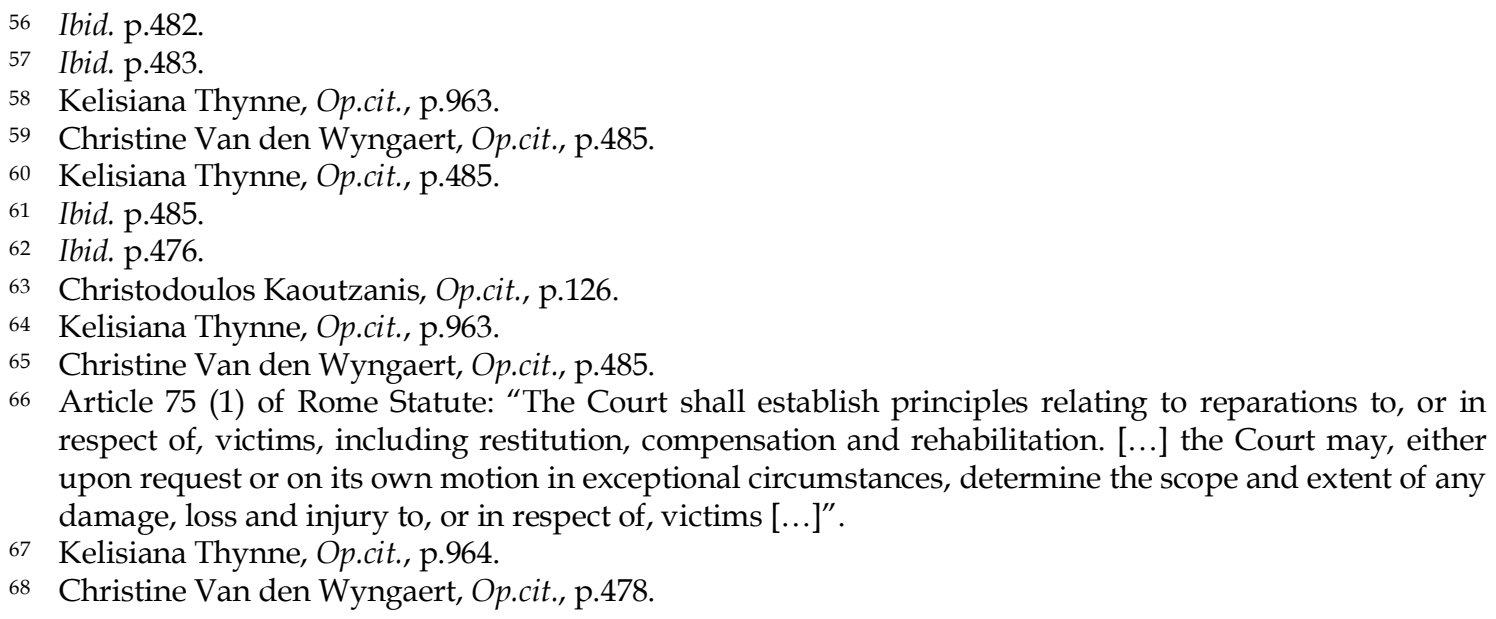
respect of, victims, including restitution, compensation and rehabilitation. [...] the Court may, either upon request or on its own motion in exceptional circumstances, determine the scope and extent of any damage, loss and injury to, or in respect of, victims [...]".

67 Kelisiana Thynne, Op.cit., p.964.

68 Christine Van den Wyngaert, Op.cit., p.478. 
pertaining to the guilt or innocence of the accused and the right to challenge the admissibility or relevance of evidence in trial proceedings lies primarily with the parties, victims can also lead the evidence." 69

It is clear that the participation of victims granted by the ICC has benefited them. Nevertheless, the role for victims at the ICC is continuing to be widely challenged by stating that in common law jurisdictions, victim participation has to be limited in order to protect the defendants' right to a fair and expeditious trial. ${ }^{70}$ The statements legitimizing victims' participation in domestic prosecution disagree with the participation in international criminal proceedings because they would not receive the same benefit as they who participate in domestic trial and cause a distributive problemparticularly it places budget on the actual but unrecognized victims of crimes within the jurisdiction of the Court and upcoming victims. A number of victims involves in international criminal crimes would be impossible for individual victim to participate in a meaningful way because a common legal representative is likely to be representing the victim as the conflicting interests and desires amongst victims. ${ }^{71}$

Furthermore, the reason that victims' participation might help the Prosecutor is challenged and in many cases wrong. ${ }^{72}$ Moreover, in terms of seeking the reparations, some commentators have stated that it is unreasonable to hope that the ICC will be able to provide enough reparations to individual claimants as based on the Prosecutor strategy to focus on high-rank officials and those most liable for serious crimes means that thousands of victims might be granted to seek reparations from a single defendant.73 Consequently, the ICC should concern on granting collective reparations that might include monuments or museums to memorialize the victims, money to rebuild destroyed buildings or the establishment of community centers. ${ }^{74}$

The argument that the participation might help the prosecution is uncertain even in many cases incorrect due to the fact that the ICC Prosecutor disagree with victims' request to participate in the proceedings especially in the investigation stage when the participation might intervene with the Prosecutor ability to conduct focused investigation, and victim participation during the trial might also frustrate the defendant's prosecution due to the different theory of the case between the Prosecutor and a victim's counsel leading them to make inconsistent arguments and undermining the prosecutor's ability to secure a conviction. ${ }^{75}$

\section{Whether the Victims' Participation Would be a Violation to the Rights of a Fair Trial of the Accused in the International Criminal Court or Not}

The participation of victims has been welcomed as one of the great inventories of the International Criminal Court system. It has been ruled in clearly by the promulgator of the Statute and the RPE of the ICC concerning trial proceeding by providing a great opportunity for victims to participate in the ICC proceedings, which is viewed as an unprecedented provision in the international perspective. The ad hoc Tribunals' Statutes and Rules, for instance are not able to allow them to participate in proceedings and to

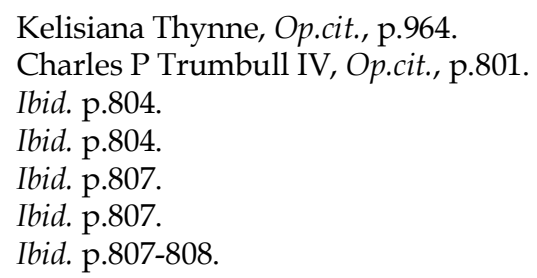


provide any compensation mechanisms for them due to physical or emotional suffering. ${ }^{76}$ The reason of the ICC Statute drafters for recognizing victims as participants, and not as only proceeding objects, is due to several considerations. Firstly, the widespread recognition of the significance of their access to justice, as underlined in the Basic Principles and Guidelines on the Right to a Remedy and Reparation for Victims of Violations of International Human Rights and Humanitarian Law and the Proposed Guiding Principles for Combating Impunity for International Crimes. ${ }^{77}$ Secondly, their interests might be different between the Prosecutor and the states' interests in admissibility or jurisdiction proceedings. ${ }^{78}$

Despite the fact that the victims are allowed to participate in the proceeding, Article 64 (2) of the Rome Statute provides that "The Trial Chamber shall ensure that a trial is fair and expeditious and is conducted with full respect for the rights of the accused and due regard for the protection of victims and witnesses". In addition, 91 (3) (b) of the RPE states that "The Chamber shall then issue a ruling on the request, taking into account the stage of the proceedings, the rights of the accused [...] the need for a fair, impartial and expeditious [...]". It is clear that both the Statute and RPE of the ICC require that proceedings are held in a fair and expeditious manner".

If victims are allowed to participate extensively, a Chamber might prolong proceedings that are considerably delayed; hence it is questioned whether it violates the accused right to a fair trial. In addition, the beginning victims' involvement in the proceedings could be deemed as problematic in terms of the presumption of innocence. Their participation might be obliging the Chamber to consider actual and substantial allegations concerning the conflict and harm experienced by individuals without the input or the presence of the defense. ${ }^{79}$

The victims participating before the ICC might face unpredicted results; in terms of protecting the due process right of the defendant, their participation might be rejected the opportunity to summon as witnesses, and they might be frustrated if their applications of the participations are rejected by the Chamber, and mass participation could jeopardize the safety of victims. ${ }^{80}$ A great number of victims would increase the cost of prosecution and it results in the decrease the number of prosecutions that can be brought. 81

To determine the maximum level of victim participation consists a three-part balancing examination that the ICC must consider. Firstly, marginal advantage of the participation against as the Prosecutor could not adequately represent the victims' interests. Secondly, the potential prejudice to the defendant due to recognizing them prior to and during the trial stage runs against the presumption of innocence due to the consideration to protect victims' through direct appearance, the testimony of victims in camera causes the defendant finds it more difficult to deny the their accusations, the victims are not compulsory to expose non-incriminatory evidence. Finally, the participation spending to victims who are not able to participate results in the limitation of the number of

76 Carsten Stahn, Hector Olasolo, Kate Gibson (2006). "Participation of Victims in Pre-Trial Proceedings of the ICC". Journal of International Criminal Justice, 4, 219, p.220.

77 Ibid. p.220-221.

78 Ibid. p.221.

79 Ibid. p.223-224.

80 Charles P Trumbull IV, Op.cit., p.809-811.

81 Ibid. p.812-816. 
suspects that can brought to trial and the delay in the application, investigation and trial stages. 82

Some has challenged their participation in the ICC as it would violate the rights of a fair trial of the accused. The objection of providing an opportunity for victims to participate before the trial can be found in the case of Prosecutor vs. Kony et al. 83 There was an objection to an excessive treatment through victims' participation system in the ICC proceedings as it disrespects the fairness of international criminal justice resulting from being prone to harming the fair trial rights and overburdening the fragility of ICC trial system. ${ }^{84}$

A basic principle of international criminal law is that every accused has the right to a fair trial existing at the domestic level in both adversarial and inquisitorial jurisdictions which is not allowed them to participate to different degrees in domestic jurisdictions. Although some believes that international criminal proceedings are naturally more complex, the permission to allow them to participate would harms the right of a fair trial of the defendant. ${ }^{85}$ For instance the violation of an accused's fair trial rights is that the right to a speedy trial, which is accepted by most human rights instruments, could be badly affected as in regard with this right, Article 67(l) (c) of the Rome Statute regulates that a Court try an accused without undue delay. ${ }^{86}$ It can be seen that Article 67 (1) (c) follows Article 14 of the International Covenant on Civil and Political Rights. Therefore, the provision of a large number of victims into proceedings could almost clearly extend proceedings causing to large delays in proceedings, where the right of a fair trial of the accused to a speedy trial might arguably be breached.

One the one side, the main reason for the ICC was to end international impunity for heinous crimes. On the other side, the recent scheme of victim participation hampers the objective as recent victim certification procedures are very rigid resulting in they postpone the proceedings, infringe the due process rights of the defendant, and harm forthcoming victims. ${ }^{87}$

In Lubanga case, the victims' applications to participate in the appeal against the confirmation of charges, Patricia Annick Mongo, a duty counsel, highlighted a number of defense concerns about the excessively general nature of the applications to participate at all proceedings' stages by arguing that since victims' interests only centered on reparations, and reparation issues only arise during the trial stage, victims' participation should not take place in the Pre-Trial stage and certainly not in an appeal at the Pre-Trial stage. ${ }^{88}$ In addition, She also notified the Chambers that the allowance of victims to interfere as third parties in the proceedings would have no legal basis under the Rome Statute. 89

$82 \quad$ Ibid. p.822.

83 Submission of Information on the Status of the Warrants of Arrest in the Situation in Uganda, Prosecutorvs Kony et al., ICC-02/04-01/05-116Corr2, 6 October 2006.

84 Goran Sluiter; Sergey Vasiliev (2007). "International Criminal Court (ICC)”. Netherlands Quarterly of Human Rights, 25, 329, p.343.

85 Brianne N. McGonigle (2009). “Bridging the Divides in International Criminal Proceedings: An Examination into the Victim Participation Endeavor of the International Criminal Court". Florida Journal of International Law, 21, 93, p.140.

86 Ibid. p.140.

87 Christodoulos Kaoutzanis, Op.cit., p.128.

88 Lubanga,ICC-01/04-01/06-901-Corr-tEN, Response to the application by victims a/0001/06, a/0002/06, a/0003/06 and a/0105/06 for authorization to participate in the appeal proceedings relating to the decision on the confirmation of charges (May 11, 2006).

89 Ibid. 
In the Katanga case, Pre Trial Chamber I decided ten decisions regarding victims' matters although it is difficult to count exactly the time cancelation in lieu with the decisions namely victims' personal length and details and their communal numbers allowing one to understand which postpone the trial. ${ }^{90}$ The postponement might be detrimental to the accused rights and as a consequence, there would be a smaller number of prosecutions which is causing perpetrators continuing committing the atrocity and finally, the ICC is not able to achieve its main goal of ending immunity.

It is clear that, admissibility of certifying victims has prolonged cases that are being tried and the ability of the court to prosecute extra cases is limited. By lesser prosecution, perpetrators might continue committing crimes, creating more potential victims and preventing the ICC from ending impunity. ${ }^{91}$ In relation to time efficiency consideration and the right of a fair trial, in the Extra Ordinary Chamber of Cambodian Court held that victims who are seeking for a Civil Party only has fifteen days for making the application which is different from the previous holding of the chamber stating that one could request for a member of the Civil Party [a] $t$ any time during the judicial investigation. The reduction of its victims' participation was resulted from an aim to improve the efficiencies of the Chambers. Nevertheless, it has been argued that the holding is misstep due to the favor of increasing efficiency. ${ }^{92}$

In my view, ideally, the proceedings, the whole of the Chambers of the Court, in accordance with Articles 68 and 67 of the Rome Statute, try to provide impartial justice for parties and participants, but whether the Court should achieve such fairness is still unclear. Some argue that the Court must enforce a balance between a number of legitimate objectives. Such objectives are the right of a fair trial of the accused; the victims right to participate in proceedings, the fair trial rights of the Prosecutor and an applicable Court procedure. However, pursuant to Article 68(3) of the Rome Statute views that the rights of victims should not come at the expense of defense rights. Therefore, the rights of the defendant have always to be more important. The scheme of compensation that has been introduced by the ICC as an international criminal court having jurisdiction to try individuals is better compared to the European Court of Human Right as it might cause the litigants spend a lot of money in litigating their rights before the court. 93

I believe that it is not easy to balance between the rights of victims' participation and the accused rights in the ICC regime, and it would be true that the ICC has not been able to maximize the benefits of victim participation yet. It is not surprised facts because the Rome Statute itself is still claimed as the rudimentary rule in relation to the enforcement of international criminal law. These research findings would be contributing to the development of the victims' roles in the ICC in terms of protecting their rights and ensuring the right of the defendants to obtain a fair trial in the ICC regime

90 Christodoulos Kaoutzanis, Op.cit, p.130.

$91 \quad$ Ibid. p.818.

92 David S. Sokol (2011). "Reduced Victim Participation: A Misstep by the Extraordinary Chambers in the Courts of Cambodia". Washington University Global Studies Law Review, 10, 167., p.171.

93 Mahfud. (2014). "Extra-Territorial Torture and Inhuman Treatment towards Suspected Terrorists Committed by the U.K. and the U.S. Military Actions". Indonesian Journal of International Law, 11 (2), 219, p.250. 


\section{Conclusion}

To sum up, the roles of victims in the International Criminal Court are to participate at the proceeding and to reparation. In relation to the right of victim to participate at the proceeding, pursuant to Article 68 (3) of the Rome Statute, the presentation of their views and concerns are allowed and considered by the Court in case their personal interests are affected. However, in Lubanga case, the Appeal Chamber states that victims can also lead the evidence. Victims are also entitled to seeking the reparations although it is impossible to expect that the ICC will be able to provide enough reparations to individual applicants who seek reparations from a single accused. Regarding, the breach of a fair trial right of the accused due to victims' participation in the proceeding, In my view, it would infringe the due process rights of the defendants. However, I believe that by strict scrutiny of the ICC in determining which potential victims should be take part as witnesses might end international impunity for heinous crimes perpetrators and keep a time - efficient trial process of the ICC.

\section{References}

Brianne N. McGonigle (2009). Bridging the Divides in International Criminal Proceedings: An Examination into the Victim Participation Endeavor of the International Criminal Court. Florida Journal of International Law, 21, 93.

Carsten Stahn, Hector Olasolo, Kate Gibson (2006). Participation of Victims in Pre-Trial Proceedings of the ICC. Journal of International Criminal Justice, 4, 219.

Charles P. Trumbull IV (2007). The Victims of Victim Participation in International Criminal Proceedings", Michigan Journal of International Law, 29, 777.

C. Byron (2007). A Blurring of the Boundaries: The Application of International Humanitarian Law by Human Rights Bodies. Virginia Journal of International Law, $47,839$.

Christine Van den Wyngaert (2011). Victims Before International Criminal Courts: Some Views and Concerns of an ICC Trial Judge. Case Western Reserve Journal of International Law, 44, 475.

Christodoulos Kaoutzanis (2010). Two Birds with One Stone: How the Use of the Class Action Device for Victim Participation in the International Criminal Court Can Improve Both the Fight against Impunity and Victim Participation. U.C. Davis Journal of International Law \& Policy, 17, 111.

Colin T. McLaughlin (2007). Victim and Witness Measures of the International Criminal Court: A Comparative Analysis. The Law and Practice of International Courts and Tribunals, 6, 189.

David S. Sokol (2011). Reduced Victim Participation: A Misstep by the Extraordinary Chambers in the Courts of Cambodia. Washington University Global Studies Law Review, 10, 167.

Giovanna M. Frisso (2011). The Winding Down of the ICTY: The Impact of the Completion Strategy and the Residual Mechanism on Victims. Goettingen Journal of International Law, 3, 1093.

Goran Sluiter; Sergey Vasiliev (2007). International Criminal Court (ICC). Netherlands Quarterly of Human Rights, 25, 329. 
Jocelyn Courtney, Christodoulos Kaoutzanis (2015). Proactive Gatekeepers: The Jurisprudence of the ICC's Pre-Trial Chambers. Chicago Journal of International Law, $15,518$.

Kelisiana Thynne (2009). The International Criminal Court: A Failure of International Justice For Victims?. Alberta Law Review, 46, 957.

Kristina Hon (2013). Bringing Cultural Genocide In By The Backdoor: Victim Participation at The ICC. Seton Hall Law Review, 43, 359.

Liesbeth Zegveld (2010). Victims' Reparations Claims and International Criminal Courts: Incompatible Values?. Journal of International Criminal Justice, 8, 79.

Mahfud (2014). Extra-Territorial Torture and Inhuman Treatment towards Suspected Terrorists Committed by the U.K. and the U.S. Military Actions. Indonesian Journal of International Law, 11 (2), 219.

Michael Bachrach (2000). The Protection and Rights of Victims under International Criminal Law. Journal of International Law, 34, 7.

Miriam Cohen (2008). Victims' Participation Rights Within the International Criminal Court: A Critical Review. Denver Journal of International Law and Policy, 37, 351.

Muladi (2004). International Criminal Court (ICC) in Comparison with the Indonesian Human Rights Court, Indonesian Journal of International Law, 1 (4), 659.

Salvatore Zapala (2010). The Rights of Victims v. the Rights of the Accused. Journal of International Criminal Justice, 8, 137.

The Rome Statute of the International Criminal Court, July 1, 2002, 2187 U.N.T.S.90

International Criminal Court, Rules of Procedure and Evidence. The Rules of Procedure and Evidence are reproduced from the Official Records of the Assembly of States Parties to the Rome Statute of the International Criminal Court, First session, New York, 3-10 September 2002 (ICC-ASP/1/3 and Corr.1), part II.A.

The Declaration of Basic Principles of Justice for Victims of Crime and Abuse of Power that was adopted by the United Nation General Assembly 1985.

Prosecutor v. Thomas Lubanga Dyilo, ICC-0 1/04-01/06, Judgment on the appeals of The Prosecutor and The Defence against Trial Chamber l's Decision on Victims' Participation of 18 January 2008 (11 July 2008) at para. 96 (International Criminal Court, Appeals Chamber)

Submission of Information on the Status of the Warrants of Arrest in the Situation in Uganda, Prosecutorvs Kony et al., ICC-02/04-01/05-116Corr2, 6 October 2006.

Lubanga,ICC-01/04-01/06-901-Corr-tEN, Response to the application by victims a/0001/06, a/0002/06, a/0003/06 and a/0105/06 for authorization to participate in the appeal proceedings relating to the decision on the confirmation of charges (May 11, 2006).

\section{Conflict of Interest Statement:}

The author(s) declares that the research was conducted in the absence of any commercial or financial relationships that could be construed as a potential conflict of interest.

Copyright (C) 2019 HALREV. All rights reserved. 